Article

\title{
Transport Models of Ammonium Nitrogen in Wastewater from Rare Earth Smelteries by Reverse Osmosis Membranes
}

\author{
Shuanglin Gui ${ }^{1,2}$, Zhaohuan Mai ${ }^{2, *}$, Jiaqi Fu ${ }^{2}$, Yuansong Wei ${ }^{2,3}$ and Jinbao Wan ${ }^{1, *}$ \\ 1 College of Environmental Resources and Chemical Engineering, Nanchang University, Nanchang 330029, \\ China; gs1503@163.com \\ 2 Institute of Energy Conversion, Jiangxi Academy of Sciences, Nanchang 330096, China; fujqcc@163.com (J.F.); \\ yswei@rcees.ac.cn (Y.W.) \\ 3 State Key Joint Laboratory of Environmental Simulation and Pollution Control, Research Center for \\ Eco-Environmental Sciences, Chinese Academy of Sciences, Beijing 100085, China \\ * Correspondence: vivianmzh@hotmail.com (Z.M.); jinbwan@163.com (J.W.)
}

Received: 16 June 2020; Accepted: 30 July 2020; Published: 3 August 2020

\begin{abstract}
Wastewater from rare earth smelteries contains large amounts of ammonium nitrogen $\left(\mathrm{NH}_{4}{ }^{+}-\mathrm{N}\right)$, which causes severe environmental problems. In this contribution, the desalination efficiency of reverse osmosis (RO) was investigated in the treatment of $\mathrm{NH}_{4} \mathrm{Cl}$ or $\mathrm{NaCl}$ solutions from 0.1 to $40 \mathrm{~g} / \mathrm{L}$ under different operating pressures with a commercial $\mathrm{RO}$ membrane. Experimental results showed that when an operating pressure above 30 bar is applied to the $5 \mathrm{~g} / \mathrm{L}$ $\mathrm{NH}_{4} \mathrm{Cl}$ solution, the permeate was found to meet the discharge standards of $\mathrm{NH}_{4}{ }^{+}-\mathrm{N}$. Compared to $\mathrm{NH}_{4} \mathrm{Cl}$, the permeate fluxes of $\mathrm{NaCl}$ solutions were higher due to the higher net driving force and lower propensity to membrane fouling. Theoretical models indicate a linear relationship between water flux and the net driving force for both $\mathrm{NH}_{4} \mathrm{Cl}$ and $\mathrm{NaCl}$ solutions. On the contrary, a power function between the salt flux and concentration difference correlated well with the experimental data for salt transport. The equations for water and salt transport obtained by this work would provide a facile and practical means for predicting the membrane performance in design and optimization of $\mathrm{RO}$ processes for the treatment of wastewater from the rare earth industry.
\end{abstract}

Keywords: ammonium nitrogen; reverse osmosis; mass-transfer model; concentration polarization; rare earth industry

\section{Introduction}

In the past two decades, the demand for rare earth elements (REEs) underwent an explosion due to the widespread application of REEs in daily life, such as cell phones, computer memory, rechargeable batteries, fluorescent lighting, magnets, etc [1]. China has abundant rare earth resources, which contribute an average share of over $85 \%$ to the global REEs supply in the last twenty years [2]. However, during the REEs smelting process, large quantities of chemicals are used. Especially in the extraction stage, ammonium hydroxide $\left(\mathrm{NH}_{4} \mathrm{OH}\right)$ is added to saponify the acidic extractants, resulting in an annual discharge of ten million tons of wastewater with a high content of ammonium nitrogen $\left(\mathrm{NH}_{4}{ }^{+}-\mathrm{N}\right)$, which generally ranges from 300 to $40,000 \mathrm{mg} / \mathrm{L}$ in different stages (e.g., extraction, precipitation and washing stages) and is far above the national discharge standards in the rare earth industry (GB26451-2011) [3-5]. Furthermore, it is reported that the washing wastewater from the REEs precipitation process mainly contains $\mathrm{NH}_{4}{ }^{+}-\mathrm{N}$, while other parameters (e.g., REEs, heavy metals, COD, TP) are lower than the discharge standards [6,7]. Direct discharge of wastewater with high content of $\mathrm{NH}_{4}{ }^{+}-\mathrm{N}$ will not only waste a lot of resources, but will also induce high environmental risks, such as 
eutrophication and excessive propagation of algae [3]. Therefore, developing reliable technologies for $\mathrm{NH}_{4}{ }^{+}-\mathrm{N}$ discharge in the rare earth industry is of great concern for sustainable water reuse and cleaner production from the economic and environmental perspectives.

Conventional technologies, such as ammonia stripping, evaporation crystallization and struvite precipitation, are widely applied in high strength $\mathrm{NH}_{4}{ }^{+}-\mathrm{N}$ wastewaters [6-8]. However, the disadvantages of these methods such as high energy consumption, secondary pollution and/or demand for advanced treatment to meet the discharge standards, render them techno-economically inefficient and hinder their wider applications. Biochemical technologies also present significant challenges in high strength $\mathrm{NH}_{4}{ }^{+}-\mathrm{N}$ wastewaters because of the high salt concentration and lack of organics $[6,7]$.

Membrane technology, especially reverse osmosis (RO), featured as environmentally friendly, easy to operate and requiring no additional chemicals, stands out as a competitive alternative to treat rare earth wastewater [9]. The driving force of $\mathrm{RO}$ is pressure difference, that is, when the operating pressure is higher than the osmotic pressure of the feed solution, water molecules can pass through the RO membrane, and most of the raw water in the inorganic salts, organic matter, colloid and microorganisms will be retained for the size sieve effect of the RO membrane. RO is mostly used for the desalination of brackish water with salt concentration under $10,000 \mathrm{mg} / \mathrm{L}$ and seawater with salt concentration in the range of 35,000-40,000 $\mathrm{mg} / \mathrm{L}$ for their high efficiency on the separation/concentration of organic matters, salts and even monovalent ions [10]. The reported values of $\mathrm{NH}_{4}{ }^{+}-\mathrm{N}$ concentration in wastewater generated from the rare earth industry fall in the range of salt concentrations in brackish water and seawater RO membranes. Thus, $\mathrm{RO}$ is expected to have potential as an advanced wastewater treatment technology for rare earth smeltery wastewater with high concentrations of $\mathrm{NH}_{4}{ }^{+}-\mathrm{N}$.

However, the application of $\mathrm{RO}$ in treating rare earth smeltery wastewater is rather limited, and the literature of $\mathrm{RO}$ application in the rare earth industry is scarce. Zhang et al. proposed an air stripping and low-pressure reverse osmosis (LPRO) combined process for the treatment of rare earth smeltery wastewater containing high concentrations of $\mathrm{NH}_{4}{ }^{+}-\mathrm{N}$ [11]. The LPRO desalination process showed high retention efficiencies of ammonia with a rejection of $95 \%$ as the $\mathrm{NH}_{4}{ }^{+}-\mathrm{N}$ concentration of the feed solution was $200-300 \mathrm{mg} / \mathrm{L}$, and the permeate could be directly discharged or reused. Huang et al. studied the feasibility of $\mathrm{RO}$ for rare earth ammonium nitrogen wastewater, and proved that the RO membrane could be used as pre-treatment when the $\mathrm{NH}_{4} \mathrm{Cl}$ concentration of real wastewater was $2.85 \mathrm{~g} / \mathrm{L}$ [12]. Moreover, many researchers focused on the application of RO processes in the removal of $\mathrm{NH}_{4}{ }^{+}-\mathrm{N}$ in other effluents [13-15]. Chang and Chung used spiral wound $\mathrm{RO}$ for ammonium pre-concentration prior to ion exchange [12].The rejection of the $\mathrm{RO}$ membrane in their study was only $10 \%$ and the permeate concentration of $\mathrm{NH}_{4}{ }^{+}-\mathrm{N}$ was $8450 \mathrm{mg} / \mathrm{L}$. Bódalo et al. investigated the performance of a cellulose acetate RO membrane in a cross-flow module for the treatment of aqueous solutions containing $55-9545 \mathrm{mg} / \mathrm{L} \mathrm{NH}_{4}{ }^{+}-\mathrm{N} \mathrm{[13].} \mathrm{A} \mathrm{solution-diffusion} \mathrm{model} \mathrm{was} \mathrm{applied} \mathrm{to}$ understand the mass transfer through the $\mathrm{RO}$ membrane, and a high rejection of $\mathrm{NH}_{4}{ }^{+}-\mathrm{N}(>98.6 \%)$ was observed. These results proved the feasibility of $\mathrm{RO}$ to decrease the concentration of $\mathrm{NH}_{4}{ }^{+}-\mathrm{N}$ in feed solutions. However, there are only a few studies on testing raw effluents with high concentration of $\mathrm{NH}_{4}{ }^{+}-\mathrm{N}$. In addition, the current research on rare earth wastewater mainly focuses on the treatment technology and process while the investigation of the mass-transfer process of rare earth wastewater in an RO membrane is rather limited. Therefore, a systematic study to examine the efficiency of RO for the desalination of high $\mathrm{NH}_{4}{ }^{+}-\mathrm{N}$ wastewater and water/salt mass transfer behavior through $\mathrm{RO}$ membranes is desirable.

As a permselective barrier, $\mathrm{RO}$ membrane performance is mainly determined by water flux and solute rejection [16]. Both parameters are dependent on membrane properties, wastewater composition, and environmental and operating conditions. Therefore, predictive modelling of water flux and salt rejection in aqueous solutions by $\mathrm{RO}$ membranes is important for the optimization and scale-up of the water treatment processes. Many researchers have investigated the mass transfer of salts by modeling the RO process [17-23]. The most commonly accepted model of $\mathrm{RO}$ was developed by Merten and 
Lonsdale based on the solution-diffusion mechanism [17,18]. This model considered that both water and solute transport through a dissolution-diffusion-desorption process. Water is driven by pressure differences across the membrane in $\mathrm{RO}$, whereas the transport of salts or ions is driven by a concentration gradient in the feed and the permeate. With this model, a linear relation is commonly expected between water flux and the pressure difference. But the nonlinear relationship of water flux has been observed under high salt concentrations in several lab-scale experiments, which could be explained by an alternative expression of the driving force [24]. On the other hand, according to Merten and Lonsdale's model, the salt flux is considered linearly related to the concentration differences. However, a power function relationship has also been reported [24]. It has been widely noted that classical transport theories and models become inconvenient to describe complex separation and transport phenomena. Hence, it is necessary to establish simple but practical transport equations to interpret experimental observations, and thus offer a clear guideline on improving the membrane performance.

The main objective of this study was thus to explore the applicability of $\mathrm{RO}$ for the treatment of the wastewater with highly concentrated $\mathrm{NH}_{4}{ }^{+}-\mathrm{N}$ from a rare earth smeltery and investigate the mass transfer mechanism. Simulated $\mathrm{NH}_{4} \mathrm{Cl}$ and $\mathrm{NaCl}$ solutions in different concentrations were tested under different operating pressures in a lab-scale setup. Theoretical and practical equations for water and salt fluxes through RO membranes were proposed based on classical theories and the observed experimental data, to investigate the water and salt transport, and to predict the RO membrane performance in real rare earth wastewater treatment. This contribution offers a new approach to the treatment and reuse of the high $\mathrm{NH}_{4}{ }^{+}-\mathrm{N}$ wastewater by $\mathrm{RO}$.

\section{Theory}

According to the solution-diffusion model established by Merten and Lonsdale $[17,18]$, the water flux in the $\mathrm{RO}$ process can be expressed as a linear function of the net driving force, which can be calculated by the following equation:

$$
J_{v}=A(\Delta p-\Delta \pi)
$$

where $J_{v}$ is water flux $\left(\mathrm{L} / \mathrm{m}^{2} \mathrm{~h}\right), A$ is the water permeability constant or water transport coefficient of the membrane ( $\mathrm{L} / \mathrm{m}^{2} \mathrm{~h}$ bar), $(\Delta p-\Delta \pi)$ is the net driving force in which $\Delta p$ and $\Delta \pi$ represent the hydraulic pressure difference (bar) and osmotic pressure difference across the membrane (bar), respectively.

The water transport coefficient $A$ is a constant for a given membrane and salt concentration, it was calculated as follows [22]:

$$
A=\frac{D_{w} N_{w} V_{w}}{R T L}
$$

where $D_{w}$ and $N_{w}$ are the diffusion coefficient and solubility of water inside the membrane, respectively, $V_{w}$ is the molar volume of water, $R$ is the gas constant, $T$ is the temperature and $L$ is the thickness of the membrane functional layer.

The osmotic pressure $\Delta \pi$ in Equation (1) is calculated as follows:

$$
\Delta \pi=i R T \Delta C_{s}=i R T\left(C_{f, s}-C_{p, s}\right)
$$

where $i$ is the number of dissociated ions from the dissolved salt $s, \Delta C_{s}$ is the salt concentration difference $(\mathrm{g} / \mathrm{L})$ between the feed and the permeate, and $C_{f, s}$ and $C_{p, s}$ are concentrations of salt $s$ in the feed and permeate solution, respectively.

The apparent salt rejection to component $s, R_{a p p, s}$, was determined using the following equation:

$$
R_{a p p, s}=1-\frac{C_{p, s}}{C_{f, s}}
$$

Combining Equations (3) and (4) yields:

$$
\Delta \pi=i R T R_{a p p, s} C_{f, s}=R_{a p p, s} \pi_{f, s}
$$


where $\pi_{f, s}$ is the feed osmotic pressure (bar).

The following equation is derived from Equation (1):

$$
J_{v}=A\left(\Delta p-R_{a p p, s} \pi_{f, s}\right)
$$

From the classical salt transport theory, the salt flux $J_{s}\left(\mathrm{~mol} / \mathrm{m}^{2} \mathrm{~h}\right)$ can be expressed as a linear function of the concentration difference between the feed and the permeate, using the solution-diffusion model [17-22]:

$$
J_{s}=-D_{s} \frac{d C_{s}}{d x}=\frac{D_{s} K_{s}}{L}\left(C_{f, s}-C_{p, s}\right)=B\left(C_{f, s}-C_{p, s}\right)=B R_{a p p, s} C_{f, s}
$$

where $D_{s}$ and $K_{s}$ are the salt diffusion coefficient inside the membrane and salt sorption coefficient between the membrane and the feed solution, respectively, and $B$ is the salt permeability constant or salt transport coefficient $\left(\mathrm{L} / \mathrm{m}^{2} \mathrm{~h}\right)$.

The permeate salt concentration, $C_{p, s}$, is determined by:

$$
C_{p, s}=\frac{J_{s}}{J_{v}}
$$

With Equations (4), (7) and (8), the salt rejection can be derived to the following expression:

$$
\frac{1}{R_{a p p, s}}=B \frac{1}{J_{v}}+1
$$

From the above equations, it can be assumed that if the linear relationship as stated in Equation (7) was correct and the plot of $1 / R_{a p p, s}$ vs. $1 / J_{v}$ should be a straight line with the same slope $B$.

\section{Materials and Methods}

\subsection{Wastewater Characteristics}

According to the characteristics of the wastewater from a rare earth separation plant in south China, the concentration of $\mathrm{NH}_{4}{ }^{+}-\mathrm{N}$ in wastewater from the extraction stage was as high as $39 \mathrm{~g} / \mathrm{L}$, while that of wastewater from the precipitation and washing stage was $0.9-10 \mathrm{~g} / \mathrm{L}[6,7]$. It should be noted that an excess of $\mathrm{HCl}$ is commonly used to dissolve REEs in the ore. In addition, $\mathrm{NaOH}$ is always added instead of $\mathrm{NH}_{4} \mathrm{OH}$ for the saponification during the extraction stage. As a result, the wastewater contains a considerable amount of $\mathrm{Na}^{+}$and $\mathrm{Cl}^{-}$as $\mathrm{NH}_{4}{ }^{+}-\mathrm{N}$, but due to its non-toxic properties, the concentration of $\mathrm{Na}^{+}$has rarely been reported in the rare earth wastewater. Consequently, to be more realistic, both ammonium chloride $\left(\mathrm{NH}_{4} \mathrm{Cl}\right)$ and sodium chloride $(\mathrm{NaCl})$ were chosen as model solutes for the RO tests in this study.

In addition, wastewater samples of the washing stage were collected from a rare earth plant in Nanchang (Jiangxi, China) to validate the accuracy of the transport models established from RO membrane performance parameters with synthetic solutions. The compositions of the real wastewater and synthetic wastewater are summarized in Table 1.

Table 1. Concentration of main pollutants in the real wastewater and the synthetic wastewater.

\begin{tabular}{ccccccc}
\hline Concentration $(\mathbf{m g} / \mathbf{L})$ & $\mathbf{p H}$ & $\mathbf{N H}_{\mathbf{4}}{ }^{\mathbf{+}} \mathbf{- N}$ & $\mathbf{C O D}$ & $\mathbf{A s}^{3+}$ & $\mathbf{P b}^{\mathbf{2 +} / \mathbf{4 +}}$ & $\mathbf{C l}^{-}$ \\
\hline Real wastewater & $6.4 \pm 0.1$ & $1.14 \times 10^{3} \pm 39$ & $46 \pm 1.8$ & $0.27 \pm 0.008$ & $0.15 \pm 0.006$ & $2.95 \times 10^{3} \pm 58$ \\
Synthetic wastewater & $6.5 \pm 0.1$ & $(0.1-40) \times 10^{3}$ & $/$ & $/$ & $/$ & $(0.1-40) \times 10^{3}$ \\
Indirect discharge standards & $6-9$ & 50 & 100 & 0.1 & 0.2 & $/$ \\
\hline
\end{tabular}

\subsection{Materials}

Commercial flat-sheet SG membranes (GE Osmonics, Minnetonka, MN, USA) with smooth surface, fouling-resistant and high retention rate against sodium chloride were used in this study, 
which has an effective separation area of $0.014 \mathrm{~m}^{2}$. The detailed information on the structure, properties, and operating parameters of the SG membrane was described elsewhere [25,26]. All membranes were equilibrated with distilled water for at least $24 \mathrm{~h}$ and stored in $5^{\circ} \mathrm{C}$ prior to use.

Ammonium chloride $\left(\mathrm{NH}_{4} \mathrm{Cl}\right.$, reagent grade, Xilong Scientific, Shantou, China) and sodium chloride $(\mathrm{NaCl}$, reagent grade, Xilong Scientific, Shantou, China) were used to make synthetic wastewater of REEs. Salt solutions were prepared with deionized water (DI water, resistance $>18 \mathrm{M} \Omega$ ) throughout this study.

\subsection{Experimental Setup}

A lab-scale cross-flow RO setup equipped with a stainless steel membrane module unit (SEPA CF II, GE Osmonics, Minnetonka, MN, USA) was used to investigate the membrane and variations of transport properties [27]. The RO system is exhibited in Figure 1; the system consists of a $30 \mathrm{~L}$ stainless steel feed tank, a high-pressure diaphragm pump (Hydro-Cell M-03S, Wanner Engineering, Minneapolis, MN, USA) controlled by a frequency converter, a feed flow meter, two pressure gauges, two bypass valves, and other accessories. A piece of flat sheet SG membrane was fixed in the cell with a feed spacer and shims. The batch experiment was conducted in a closed-loop mode, that is the feed stream was pumped from the feed tank to the membrane unit and the retentate and permeate were re-circulated back to the feed tank to keep the concentration of feed solution constant. The feedwater temperature was maintained constant by a recirculating heater/chiller (PolyScience, Niles, IL, USA). Adjustment of the transmembrane pressure and the cross-flow velocity was achieved through the pressure gauges and bypass valves located in the inlet and outlet of the membrane cell.

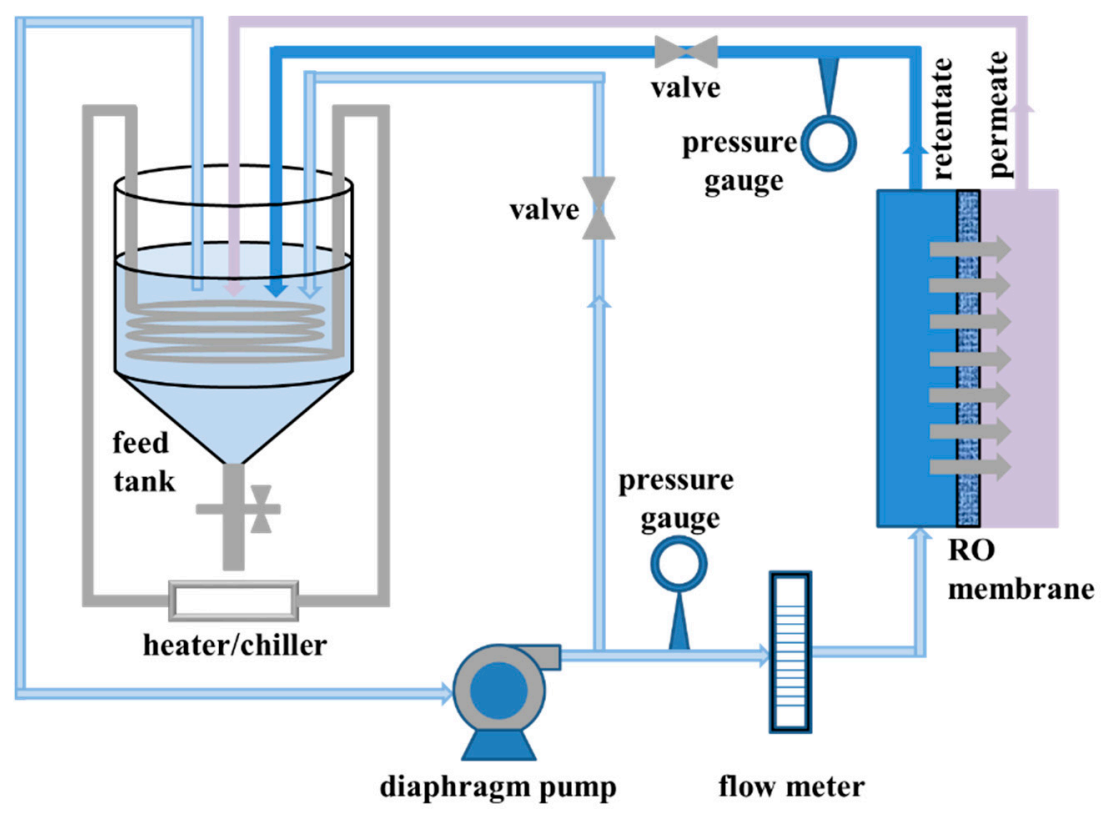

Figure 1. Schematic diagram of the lab-scale reverse osmosis (RO) setup.

\subsection{Experimental RO Process}

\subsubsection{Synthetic Salt Solutions}

Synthetic salt solutions were used in the study of $\mathrm{RO}$ membrane performance. For $\mathrm{NH}_{4} \mathrm{Cl}$ solutions, concentrations of $0.1,0.5,1,5,10,20$, and $40 \mathrm{~g} / \mathrm{L}$ were selected, respectively. The concentrations of $\mathrm{NaCl}$ solutions were set as $0.5,1,5,10,20$, and $40 \mathrm{~g} / \mathrm{L}$, respectively.

Prior to each set of filtrations, SG membranes were pre-cleaned following the procedures recommended by the manufacturer: the membrane was firstly rinsed with distilled water for $20 \mathrm{~min}$, followed by a caustic wash with an $\mathrm{NaOH}$ solution $(\mathrm{pH}=10-10.5)$ for $30 \mathrm{~min}$, and finally rinsed with 
distilled water again until the $\mathrm{pH}$ returned to neutral. All the pre-cleaning procedures were conducted at $45{ }^{\circ} \mathrm{C}$ and at an operating pressure of 30 bar.

The test membranes were then compacted with DI water at 30 bar for at least $2 \mathrm{~h}$ until a steady constant permeate flux was obtained and pure water flux was measured. Subsequently, salt solutions with different compositions were fed to the RO set-up under a flow rate of $0.5 \mathrm{~m} / \mathrm{s}$. The filtration experiments of each salt solution were performed at $25^{\circ} \mathrm{C}$ under multiple operating pressures ranging from 15 to 40 bar (unless otherwise specified in some high concentration cases) with a pressure interval of 5 bar. The salt concentrations of the permeate and the feed were measured by a DDSJ-308A conductivity meter (Leici Company, Shanghai, China) after $4 \mathrm{~h}$ of continuous operation to achieve a stable performance. In some low concentration cases, the salt concentrations of $\mathrm{NH}_{4}{ }^{+}$in the permeate were measured by Kjeldahl determination, and the concentration of $\mathrm{Na}^{+}$in the permeate was measured by an inductively coupled plasma atomic emission spectrometry Agilent 5110 ICP-OES (Agilent Technologies, Palo Alto, CA, USA). Steady state water flux under each feed salt concentration or operating pressure was also recorded.

\subsubsection{Real Wastewater Treatment}

The raw washing wastewater obtained from the rare earth plant was tested with an SG membrane under 30 bar. The other operating conditions were the same as in the previous part.

\subsubsection{Determination of Water and Salt Permeabilities}

For both synthetic and real wastewater, the steady-state permeate flux, $J_{v}\left(\mathrm{~L} / \mathrm{h} \cdot \mathrm{m}^{2}\right)$ was calculated as follows:

$$
J_{v}=\frac{V}{t \times A_{m}}
$$

where $V$ is the volume of the collected permeate (L), $t$ is the sampling duration (h), and $A_{m}$ is the effective membrane area $\left(\mathrm{m}^{2}\right)$.

The apparent salt rejection was calculated according to Equation (4). Permeate flux and solute concentration were measured for at least two consecutive samples (obtained at a given set of experimental conditions), with the average deviation below $3 \%$. For each case of given feed salt concentration and operating pressure, at least two sets of experiments were conducted to gauge the variability between different membranes. The average values of the comparative experiments were presented, accompanied with the standard deviations.

\section{Results and Discussion}

\section{1. $\mathrm{NH}_{4} \mathrm{Cl}$ Removal Performance of $\mathrm{RO}$ Membrane}

The dependence of (a) permeate flux $J_{v}$ and (b) apparent rejection $R_{a p p, N H 4 C l}$ on operating pressure at different $\mathrm{NH}_{4} \mathrm{Cl}$ concentrations are plotted in Figure 2. It can be found that the water flux increases with the operating pressure for a given salt concentration. For $1 \mathrm{~g} / \mathrm{L} \mathrm{NH} \mathrm{N}_{4} \mathrm{Cl}$ solution, the flux gradually increases from $17.86 \mathrm{~L} / \mathrm{m}^{2} \mathrm{~h}$ at 15 bar to $40.48 \mathrm{~L} / \mathrm{m}^{2} \mathrm{~h}$ at 35 bar. It can be explained by Equation (1) that at the same salt concentration, the increase of operating pressure would enhance the net driving force for water transport, thus resulting in a higher water flux. Especially, the relationship between pure water flux and the operating pressure was found to be linear, and plotting $J_{v}$ vs. $\Delta p$ in Figure 2a yields the value of $A$ in Equation (1) equal to $1.96 \mathrm{~L} / \mathrm{m}^{2} \mathrm{~h}$ bar. The determined pure water permeability of the SG membrane just falls in the $A$-value ranges of commercially available polyamide seawater membranes [28], but is slightly lower than the values reported in previous studies for the SG membrane $\left(2.46 \mathrm{~L} / \mathrm{m}^{2} \mathrm{~h}\right.$ bar), possibly due to different filtration configurations and operating conditions $[25,26]$. 
(a)

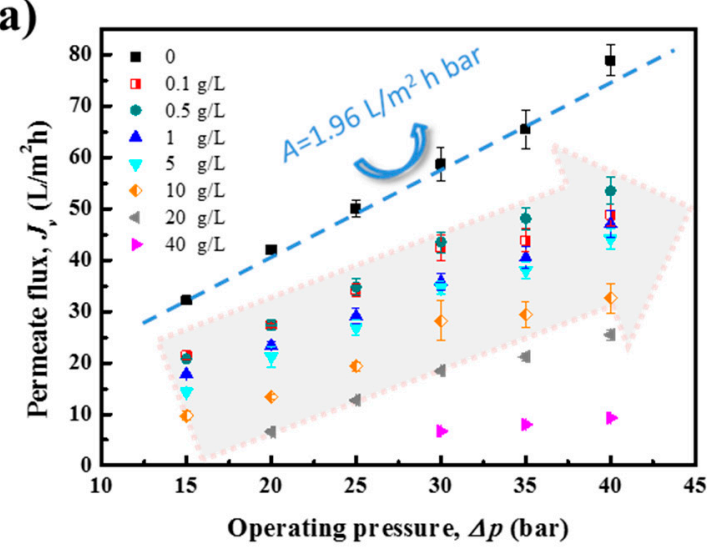

(b)

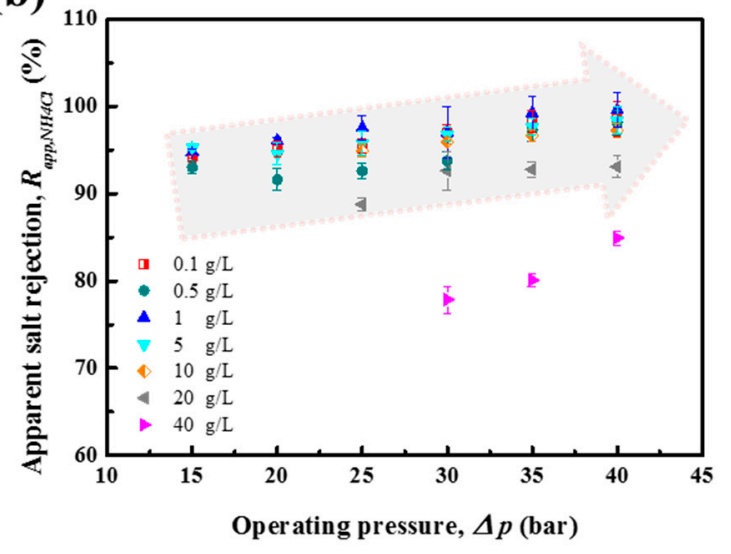

Figure 2. (a) Permeate flux $J_{v}$ and (b) apparent rejection $R_{a p p, N H 4 C l}$ vs. operating pressure $\Delta p$ at different feed concentrations of $\mathrm{NH}_{4} \mathrm{Cl}$ solution for the $\mathrm{SG}$ membrane.

As shown in Figure 2a, there is also a strong correlation between water flux and the $\mathrm{NH}_{4} \mathrm{Cl}$ concentration in the feed solution. The water flux decreases with increasing $\mathrm{NH}_{4} \mathrm{Cl}$ concentration. An elevated concentration yields a higher osmotic pressure and thus reduces the net driving force, as described in Equations (3) and (1), respectively. It is interesting that there was almost no permeate flux of the $20 \mathrm{~g} / \mathrm{L}$ feed solution at operating pressures below 20 bar, mainly because at this condition, the calculated osmotic pressure (Equation (5)) in the upstream of the membrane was as high as 18.53 bar. The net driving force $(\Delta p-\Delta \pi)$ presented only a weakened drive of water molecules across the SG membrane. However, at $40 \mathrm{~g} / \mathrm{L}$, a very low permeate flux was still observed at 30 bar even though $\pi_{f, s}$ was 37.06 bar at this concentration. This might be caused by the low rejection of $\mathrm{NH}_{4} \mathrm{Cl}$ $\left(R_{a p p, N H 4 C l}=77.87 \%\right)$ which contributed to $\Delta \pi=28.86$ bar in this case. Furthermore, the increase of salt concentration was reported to enhance the viscosity of the salt solution, which might lead to a slower diffusion process of the water molecules in the membrane, thereby causing a decline of the water flux [29].

The effect of operating pressure and salt concentration on the apparent $\mathrm{NH}_{4} \mathrm{Cl}$ rejection is exhibited in Figure 2b. The general trend for all feed solutions indicates that the apparent salt rejection increases with the operating pressure, which is consistent with previous observations for $\mathrm{RO}$ and $\mathrm{NF}[14,29]$. When the concentrations below $10 \mathrm{~g} / \mathrm{L}$, the rejection of $\mathrm{NH}_{4} \mathrm{Cl}$ slightly decreases with the increase of $\mathrm{NH}_{4} \mathrm{Cl}$ concentration in the feed water. In contrast, at higher concentrations, $R_{a p p, N H 4 C l}$ drops dramatically to around or even below 90\%. According to Equation (8), the permeate salt concentration, $\mathrm{C}_{p, \mathrm{NH} 4 \mathrm{Cl}}$, is dependent on the ratio of salt flux to water flux. The salt flux, $J_{s}$, as indicated in Equation (7), is driven by the concentration difference and is approximately independent of pressure. Generally speaking, increasing the salt concentration in feeds enlarges the salt concentration difference between the feed and the permeate. Therefore, the driving force for salt transport is enhanced 
accordingly, leading to an enhanced $\mathrm{NH}_{4} \mathrm{Cl}$ permeation. Thus, the apparent salt rejection was reduced. Furthermore, as aforementioned, it was inferred that increasing the operating pressure yields a higher water flux, resulting in a lower $\mathrm{NH}_{4} \mathrm{Cl}$ concentration in the permeate; consequently, the apparent salt rejection was augmented. Moreover, concentration polarization at high feed concentration also decreased the observed rejection.

In concentrated systems (e.g., 20 and $40 \mathrm{~g} / \mathrm{L} \mathrm{NH} \mathrm{N}_{4} \mathrm{Cl}$ ), the osmotic pressure is significantly high. Thus, the volumes of the collected permeate were not sufficient for concentration measurement, and as a result, it was difficult to calculate the apparent rejection of these solutions.

From the above discussion, it is noticeable that the removal efficiency of SG membranes is considerable, especially at low $\mathrm{NH}_{4} \mathrm{Cl}$ concentrations $(<10 \mathrm{~g} / \mathrm{L})$. The rejection of $\mathrm{NH}_{4} \mathrm{Cl}$ ranged from $77.87 \%$ to $99.58 \%$ and the permeate flux was between 6.69 and $53.14 \mathrm{~L} / \mathrm{m}^{2} \mathrm{~h}$ in the studied range of pressures and feed concentrations. As the $\mathrm{NH}_{4}{ }^{+}-\mathrm{N}$ concentration of feed solution was $1.31 \mathrm{~g} / \mathrm{L}$ (corresponding to $5 \mathrm{~g} / \mathrm{L} \mathrm{NH}_{4} \mathrm{Cl}$ ), the permeate could meet the emission standards of $\mathrm{NH}_{4}{ }^{+}-\mathrm{N}$ in the rare earth industry ( $50 \mathrm{mg} / \mathrm{L}$ for indirect discharge) when operating pressure was above 30 bar. Thus, it can be concluded that wastewater containing $1.31 \mathrm{~g} / \mathrm{L} \mathrm{NH}_{4}{ }^{+}-\mathrm{N}$ or below can be discharged or reused by the RO process with the SG membrane without additional treatment.

\section{2. $\mathrm{NaCl}$ Removal Performance of RO Membrane}

Figure 3 represents the influence of operating pressure and feed concentrations of $\mathrm{NaCl}$ on the (a) permeate flux $J_{v}$ and (b) apparent rejection of $R_{a p p, N a C l}$, in equilibrium state for SG membranes. The permeate flux and apparent rejection of $\mathrm{NaCl}$ increase with operating pressure, while both decreased with the increasing feed concentration. Moreover, the undetected permeate flux and apparent salt rejection at low pressures in $40 \mathrm{~g} / \mathrm{L}$ solution can also be explained by the high osmotic pressure and the phenomenon of concentration polarization, as discussed in the previous section.
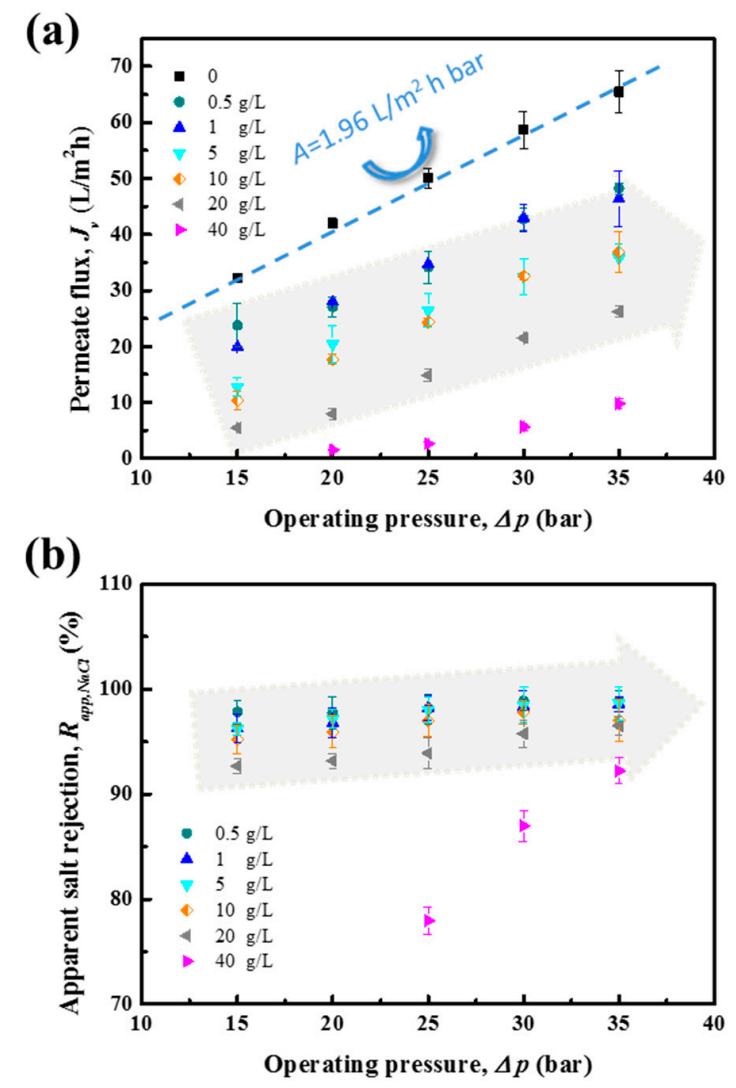

Figure 3. (a) Permeate flux $J_{v}$ and (b) apparent rejection of $R_{a p p, N a C l}$ vs. operating pressure $\Delta p$ under different feed concentrations of $\mathrm{NaCl}$ solution for the SG membrane. 
In general, the dependence of permeate flux and apparent salt rejection on operating pressure and feed concentration of $\mathrm{NaCl}$ solutions is similar to that of $\mathrm{NH}_{4} \mathrm{Cl}$ solutions. However, there are some differences in the water and salt transport between the two salt solutions. Firstly, the permeate flux of $\mathrm{NaCl}$ solutions in the RO process with an SG membrane was found to be relatively higher under the same experimental conditions at low concentrations $(<10 \mathrm{~g} / \mathrm{L})$. The reason was believed to be the higher molar concentration of $\mathrm{NH}_{4} \mathrm{Cl}$ at the same mass concentration of $\mathrm{NH}_{4} \mathrm{Cl}$ and $\mathrm{NaCl}$, which causes higher osmotic pressure and lower driven force. Secondly, the concentration polarization was more severe for the $\mathrm{NH}_{4} \mathrm{Cl}$ solution. It was found that the concentration polarization was noticeable especially at lower transmembrane pressures for $20 \mathrm{~g} / \mathrm{L} \mathrm{NH}_{4} \mathrm{Cl}$ solution. As a result, a dense crystal layer might be formed on the membrane surface, thus preventing the mass transfer of $\mathrm{NH}_{4} \mathrm{Cl}$ molecules. Permeate flux was still observed at a relatively low rate, even though the applied operating pressure was only 15 bar as $\mathrm{RO}$ was applied in the $\mathrm{NaCl}$ solution with the same concentration. Thus, it can be concluded that the $\mathrm{NH}_{4} \mathrm{Cl}$ solution has a higher fouling propensity to the $\mathrm{SG}$ membrane compared to $\mathrm{NaCl}$ at high concentrations.

Typical RO membranes are composed of three layers: a top dense and selective polyamide layer, an intermediate microporous polysulfonate layer, and a non-woven fabric support layer. By using positron annihilation spectroscopic technology, Kim et al. determined that the radius of the network pore and the aggregate pore of polyamide layer of the thin film composite (TFC) membrane were about 0.20 and $0.45 \mathrm{~nm}$, respectively [30]. Transport would be strongly hindered when the size of the pore was smaller than the hydrated radius. In this study, the apparent salt rejection of $\mathrm{NaCl}$ was observed to be slightly higher than that of $\mathrm{NH}_{4} \mathrm{Cl}$ under the same operating conditions. The selectivity between $\mathrm{Na}^{+}$and $\mathrm{NH}_{4}{ }^{+}$that was based on the hydration exclusion in the $\mathrm{RO}$ membrane was attributed to be the main reason [31-34]. The hydrated ion radius of $\mathrm{Na}^{+}(3.58 \AA)$ was larger than that of $\mathrm{NH}_{4}{ }^{+}$ (3.31 $\AA$ ) [21,23], which led to make it more difficult for the sodium ions to penetrate the membrane. This was consistent with the hydration energy of the ions, where the value of hydration energy of $\mathrm{Na}^{+}(-454 \mathrm{~kJ} / \mathrm{mol})$ was higher than that of $\mathrm{NH}_{4}{ }^{+}(-331 \mathrm{~kJ} / \mathrm{mol})[31,32]$; that well explains the higher rejection for $\mathrm{NaCl}$. In other words, the apparent rejection order of the two salt solutions is similar to the order of the hydration energy and hydration ion radius for the monovalent ions.

\subsection{Transport Models for Water and Salt Flux}

To examine the validity of the water transport model described in Equation (6), the permeate flux is plotted vs its net driving force $\left(\Delta p-R_{a p p, s} \pi_{f, s}\right)$ at different concentrations for both $\mathrm{NH}_{4} \mathrm{Cl}$ and $\mathrm{NaCl}$ solutions, as illustrated in Figures 4 and 5, respectively. It is shown that for all concentrations tested in this study, the permeate flux increased linearly with the net driving force. The slopes obtained by linear regression corresponded to the water transport coefficients $(A)$ of the salt solutions, as presented in Equation (6). It can be seen from Figure 4 that the permeability coefficient of an $\mathrm{NH}_{4} \mathrm{Cl}$ solution is $1.29 \mathrm{~L} / \mathrm{m}^{2} \mathrm{~h}$ bar, which is slightly lower than the permeability coefficient of an $\mathrm{NaCl}$ solution $\left(1.35 \mathrm{~L} / \mathrm{m}^{2} \mathrm{~h}\right.$ bar) obtained from Figure 5 . Generally, the higher the $A$-value, the higher the productivity of water. This is coincident with the results in the previous section, where the permeate flux of the $\mathrm{NaCl}$ solution was higher than that of the $\mathrm{NH}_{4} \mathrm{Cl}$ solution at the same concentration. Both $A$-values of the salt solutions were lower than the pure water permeability coefficient and were consistent with the $A$-values of high salinity solutions in RO processes reported in the literature [22,28]. The good agreement between literature data and predicted data from this study proves the efficiency and accuracy of the transport model described in Equation (6) for calculating the water flux during RO. Furthermore, the permeability coefficient $A$ is determined by the membrane property, and is independent of operating conditions, such as pressure and salt concentration. Thus, it can be used for $\mathrm{RO}$ performance evaluation and prediction in the application of rare earth wastewater desalination with concentrations of $\mathrm{NH}_{4} \mathrm{Cl}$ or $\mathrm{NaCl}$ up to $40 \mathrm{~g} / \mathrm{L}$. 


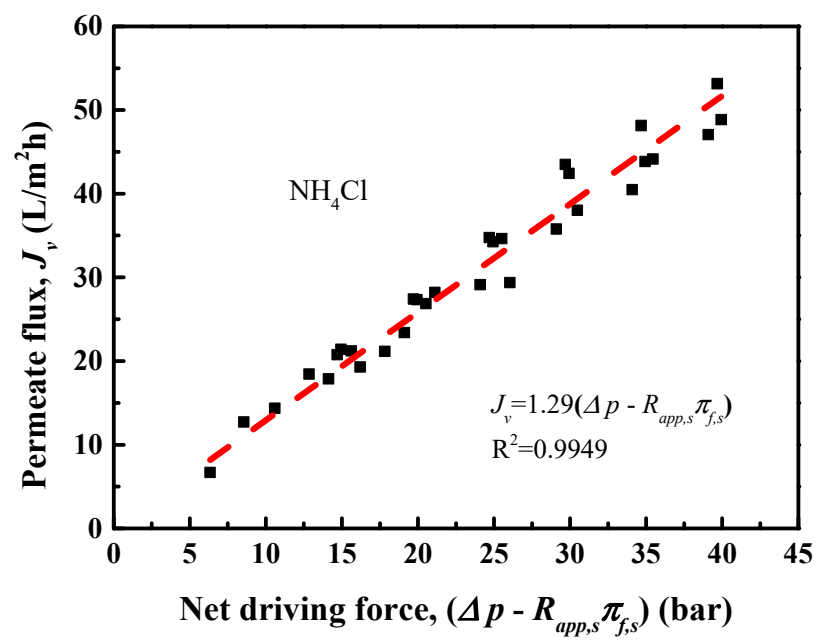

Figure 4. Correlation of permeate flux with the net driving force at different feed concentrations of $\mathrm{NH}_{4} \mathrm{Cl}$ solutions. The slope of the curve-fitting is the $A$-value in Equation (1) for SG membranes with $\mathrm{NH}_{4} \mathrm{Cl}$ solutions.

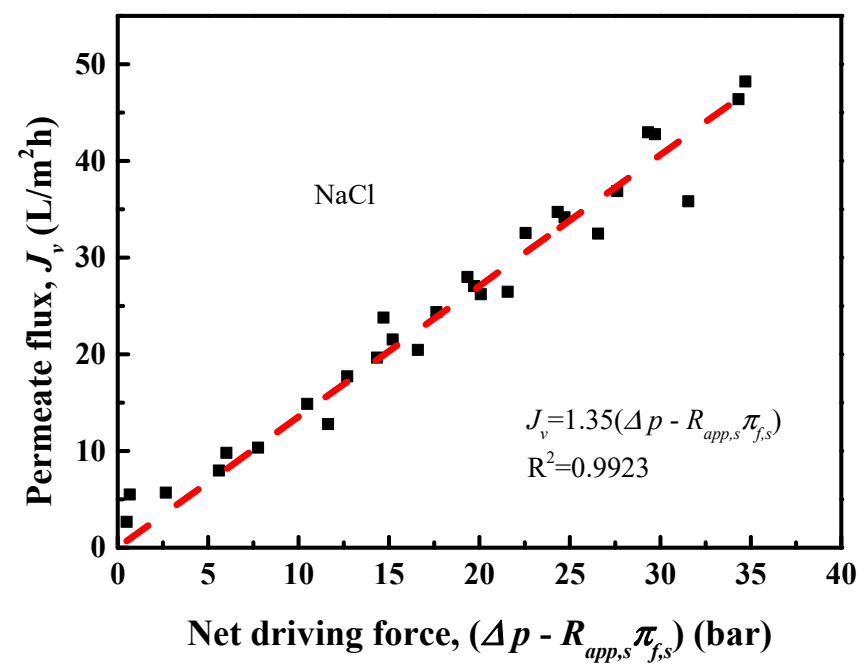

Figure 5. Correlation of permeate flux with the net driving force at different feed concentrations of $\mathrm{NaCl}$ solutions. The slope of the curve-fitting is the $A$-value in Equation (1) for SG membranes with $\mathrm{NaCl}$ solutions.

As for the salt transport during the RO process, it was assumed that if the salt permeability coefficient $B$ in Equation (7) is constant, the linear relationship between $1 / R_{\mathrm{app}, \mathrm{s}}$ and $1 / J_{v}$ in Equation (9) would hold true. However, the experimental rejection data for the SG membrane with both $\mathrm{NH}_{4} \mathrm{Cl}$ and $\mathrm{NaCl}$ solutions produced curves rather than straight lines as plotted in Figures 6 and 7 for each salt. The $B$-values and $R^{2}$ values from regression are listed in Table 2 . The low $R^{2}$ values indicate that salt fluxes through the SG membrane might not be accurately described with the linear relationship of the corresponding driving force. Since the separation and transport mechanism of membranes are complicated, the effect of a concentration gradient on salt transport is always found to deviate from a linear trend [24]. 


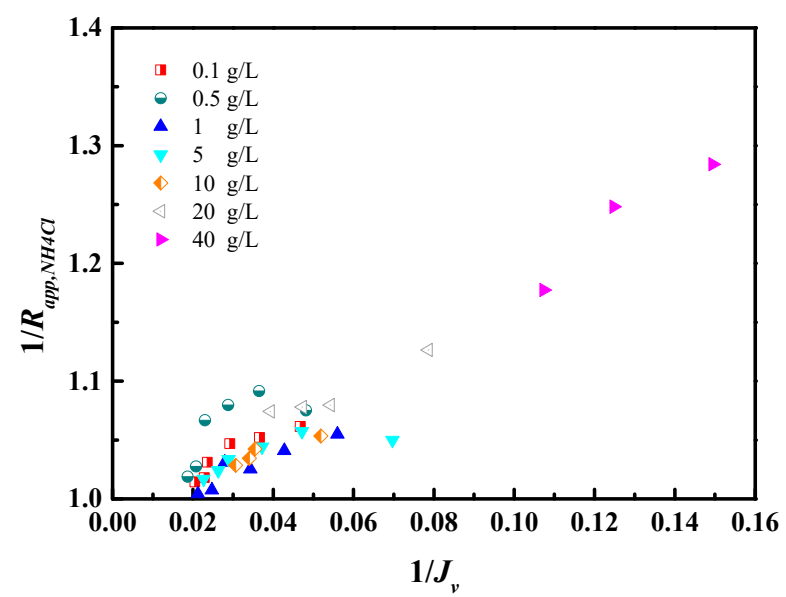

Figure 6. The correlation of $1 / R_{a p p, N H 4 C l}$ and $1 / J_{v}$ at different feed concentrations of $\mathrm{NH}_{4} \mathrm{Cl}$ solutions.

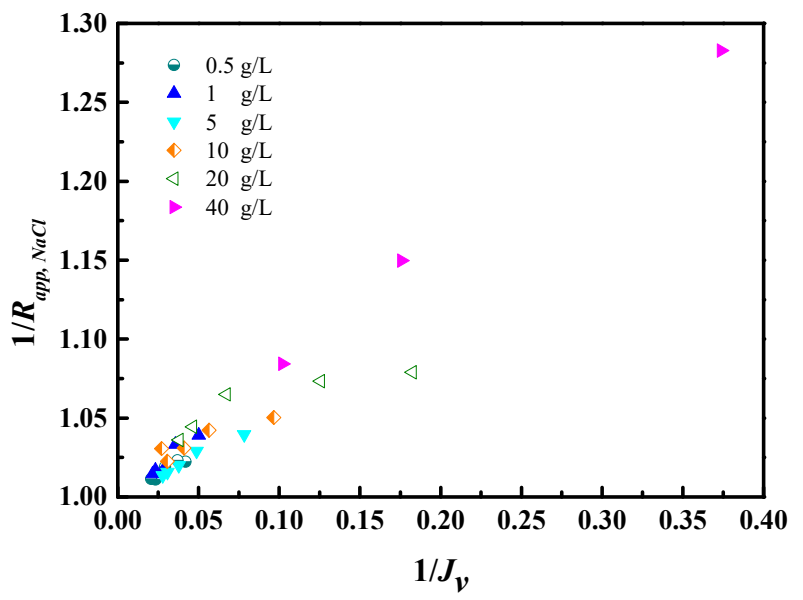

Figure 7. The correlation of $1 / R_{a p p, N a C l}$ and $1 / J_{v}$ at different feed concentrations of $\mathrm{NaCl}$ solutions.

Table 2. Summary of the regression coefficient $B$ and $R^{2}$ values with Equation (9) for $\mathrm{NH}_{4} \mathrm{Cl}$ and $\mathrm{NaCl}$ solutions.

\begin{tabular}{cccccc}
\hline & $\mathrm{NH}_{4} \mathbf{C l}$ & \multicolumn{3}{c}{$\mathbf{N a C l}$} \\
\hline$C_{f}(\mathrm{~g} / \mathrm{L})$ & $\boldsymbol{B}\left(\mathrm{L} / \mathbf{m}^{2} \mathbf{h}\right)$ & $\boldsymbol{R}^{\mathbf{2}}$ Value & $C_{f}(\mathrm{~g} / \mathrm{L})$ & $\boldsymbol{B}\left(\mathbf{L} / \mathbf{m}^{2} \mathbf{h}\right)$ & $\boldsymbol{R}^{\mathbf{2}}$ Value \\
\hline 0.1 & 1.29 & 0.7886 & 0.1 & - & - \\
\hline 0.5 & 2.02 & 0.4879 & 0.5 & 0.57 & 0.8650 \\
\hline 1 & 0.86 & 0.7269 & 1 & 0.78 & 0.8855 \\
\hline 5 & 0.93 & 0.5400 & 5 & 0.53 & 0.9666 \\
\hline 10 & 1.05 & 0.8776 & 10 & 0.63 & 0.2095 \\
\hline 20 & 1.62 & 0.9011 & 20 & 0.55 & 0.342 \\
\hline 40 & 1.8707 & 0.8671 & 40 & 0.78 & 0.9876 \\
\hline
\end{tabular}

Recently, a reformulated solution-diffusion model incorporating activity coefficients was proposed for solute transport in $\mathrm{RO} / \mathrm{NF}[35,36]$. In this model, the salt concentration was corrected with salt activity, which has a strong nonlinearity with the actual measured salt concentrations, to calculate the solute transport. Neglecting the salt activity might explain the erratic phenomenological $B$-values observed in the literature and in this work.

Since theoretical models contain several coefficients, it is much more practical to establish simple mathematical equations instead of complicated theoretical models for optimizing operational processes 
during the treatment of industrial wastewaters. Herein, a power relationship between salt flux and the concentration difference is assumed in the salt transport. The mathematical equation is hypothesized as follows [24]:

$$
J_{s}=\beta\left(C_{f, s}-C_{p, s}\right)^{\alpha}
$$

where $\beta$ is a correlation coefficient and $\alpha$ is the power function coefficient. With Equations (8) and (11), the following equation is derived:

$$
\log \left[J_{v} C_{f, s}\left(1-R_{a p p, s}\right)\right]=\alpha \log \left(C_{f, s} R_{a p p, s}\right)+\log \beta
$$

The parameters $\alpha$ and $\beta$ can be obtained from the linear regression of $\left\{\log \left[J_{v} C_{f, s}\left(1-R_{a p p, s}\right)\right]\right\}$ with $\left\{\log \left(C_{f, s} R_{a p p, s}\right)\right\}$. The plots of $\left\{\log \left[J_{v} C_{f, s}\left(1-R_{a p p, s}\right)\right]\right\}$ vs. $\left\{\log \left(C_{f, s} R_{a p p, s}\right)\right\}$ at different operating pressures are shown in Figures 8 and 9 for $\mathrm{NH}_{4} \mathrm{Cl}$ and $\mathrm{NaCl}$ solutions, respectively. The coefficients $\alpha$ and $\beta$ as well as $R^{2}$ values for the transport of $\mathrm{NH}_{4} \mathrm{Cl}$ and $\mathrm{NaCl}$ are summarized in Table 3. The high $R^{2}$ values indicate that the proposed power function relationship for salt transport fits the experimental data satisfactorily.

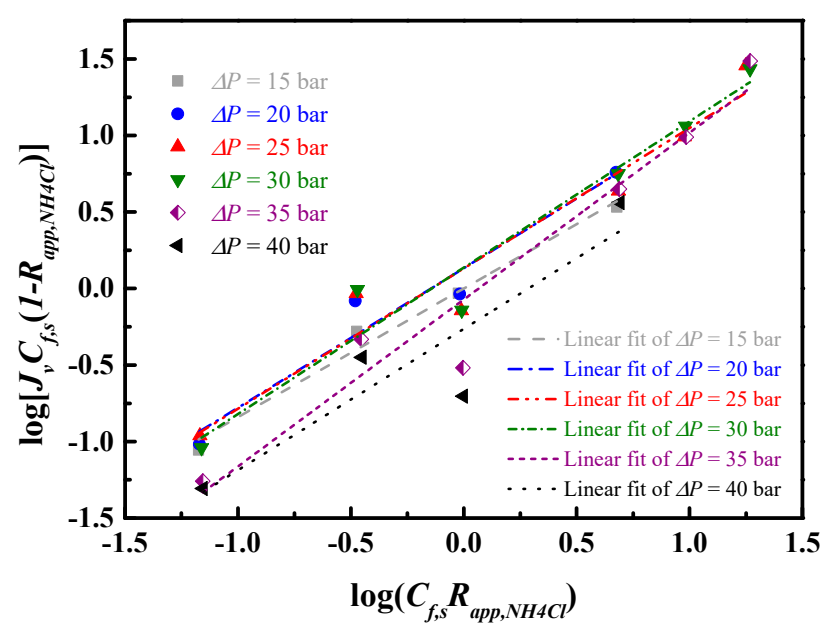

Figure 8. Correlation of $\log \left[J_{v} C_{f, s}\left(1-R_{a p p, N H 4 C l}\right)\right]$ with $\log \left(C_{f, s} R_{a p p, N H 4 C l}\right)$ determined with Equation (12), to investigate the possibility of a power relation between salt flux and the concentration difference of $\mathrm{NH}_{4} \mathrm{Cl}$ solution. The linear fit lines show good linearity.

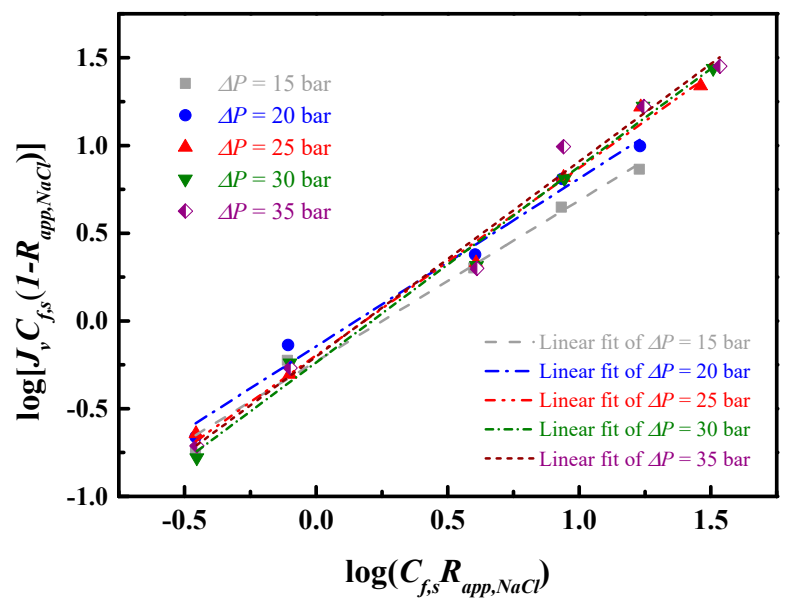

Figure 9. Correlation of $\log \left[J_{v} C_{f, s}\left(1-R_{a p p, N a C l}\right)\right]$ with $\log \left(C_{f, s} R_{a p p, N a C l}\right)$ determined with Equation (12) to investigate the possibility of a power relation between salt flux and the concentration difference of $\mathrm{NaCl}$ solution. The linear fit lines show good linearity. 
Table 3. Summary of regression coefficient $\alpha, \beta$ and $R^{2}$ values with Equation (12) for $\mathrm{NH}_{4} \mathrm{Cl}$ and $\mathrm{NaCl}$ solutions.

\begin{tabular}{ccccccc}
\hline \multirow{2}{*}{ Operating Pressure (bar) } & \multicolumn{3}{c}{$\mathbf{N H}_{\mathbf{4}} \mathbf{C l}$} & \multicolumn{3}{c}{$\mathbf{N a C l}$} \\
\cline { 2 - 7 } & $\boldsymbol{\alpha}$ & $\boldsymbol{\beta}$ & $\boldsymbol{R}^{\mathbf{2}}$ Value & $\boldsymbol{\alpha}$ & $\boldsymbol{\beta}$ & $\boldsymbol{R}^{\mathbf{2}}$ Value \\
\hline 15 & 0.84 & 1.00 & 0.9846 & 0.92 & 0.59 & 0.9882 \\
\hline 20 & 0.91 & 1.36 & 0.9491 & 0.96 & 0.72 & 0.9862 \\
\hline 25 & 0.92 & 1.36 & 0.9494 & 1.07 & 0.64 & 0.9919 \\
\hline 30 & 0.96 & 1.37 & 0.9634 & 1.12 & 0.58 & 0.9906 \\
\hline 35 & 1.09 & 0.85 & 0.9465 & 1.11 & 0.63 & 0.9840 \\
\hline 40 & 0.92 & 0.54 & 0.8458 & - & - & - \\
\hline
\end{tabular}

From Table 3, it can be concluded that the coefficient $\alpha$ of the power function showed an increasing trend with operating pressure for each salt, indicating that the nonlinearity of the salt flux increases with operating pressure. The $\alpha$ value of the $\mathrm{NaCl}$ solution is slightly higher than that of $\mathrm{NH}_{4} \mathrm{Cl}$ at the same operating pressure. Table 3 also demonstrates that the transport coefficient $\beta$ remains in the range of $0.85-1.37$ and $0.58-0.72$ for $\mathrm{NH}_{4} \mathrm{Cl}$ and $\mathrm{NaCl}$, respectively. To simplify the dependence of transport coefficients on operating conditions, which is desirable in membrane transport for process design and operational optimization, the data in Figure 8 with different operating pressures of $\mathrm{NH}_{4} \mathrm{Cl}$ system were plotted together. It can be roughly estimated that the $\alpha$ and $\beta$ values were independent of pressure and feed salt concentration for the SG membrane; the values were around 0.97 and 1.08 , respectively, for the $\mathrm{NH}_{4} \mathrm{Cl}$ solutions. The same simplification method was applied to the $\mathrm{NaCl}$ system shown in Figure 9, and it was found that the $\alpha$ and $\beta$ values are around 1.05 and 0.63 ; these values are also independent of pressure and feed salt concentration for the SG membrane.

To validate the accuracy of the proposed models for water and salt transport, real wastewater from the washing stage in a rare earth plant in Jiangxi Province (China) was tested by the SEPA CF II system with an SG membrane. The concentration of $\mathrm{NH}_{4}{ }^{+}-\mathrm{N}$ in the wastewater was $1.14 \mathrm{~g} / \mathrm{L}$, and the operating pressure was 30 bar. The predicted values as well as the experimental data of the permeate flux and apparent rejection to $\mathrm{NH}_{4}{ }^{+}-\mathrm{N}$ are summarized in Table 4 . The predicted permeate flux is slightly higher than the experimental data, due to the simplification of the model by overlooking the effect of other trace elements in the wastewater. A good agreement between predicted values and experimental data shows that the proposed equations of water and salt transport are appropriate for the prediction of the membrane performance when dealing with real wastewater.

Table 4. Comparison of the permeate flux and salt rejection between experimental data and predicted values from models with real wastewater from a rare earth plant in the Jiangxi Province (China).

\begin{tabular}{ccc}
\hline & Experimental Data & Predicted Value from Models \\
\hline Permeate flux $\left(\mathrm{L} / \mathrm{m}^{2} \mathrm{~h}\right)$ & 31.67 & 34.77 \\
\hline Apparent rejection to $\mathrm{NH}_{4}{ }^{+}-\mathrm{N}(\%)$ & 97.53 & 97.00 \\
\hline
\end{tabular}

\section{Conclusions}

Commercial $\mathrm{RO}$ membranes were used for the desalination of highly concentrated $\mathrm{NH}_{4} \mathrm{Cl}$ and $\mathrm{NaCl}$ solutions simulated as saline wastewater from the rare earth industry in this work. The apparent salt rejection rates higher than $95 \%$ were obtained in most cases for both salts (except for solutions above $20 \mathrm{~g} / \mathrm{L}$ ), indicating the high removal efficiency of SG membranes, and confirming the feasibility of using $\mathrm{RO}$ in the treatment of wastewater from the rare earth industry. Especially, the permeate of $5 \mathrm{~g} / \mathrm{L} \mathrm{NH}{ }_{4} \mathrm{Cl}$ solution could meet the requisite discharge standard of $\mathrm{NH}_{4}{ }^{+}-\mathrm{N}$. A higher rejection and flux was found for sodium compared to $\mathrm{NH}_{4}{ }^{+}-\mathrm{N}$; the larger hydrated ion size and hydration energy 
were the main reasons. The water flux followed a linear pressure-driven process as discovered by mass-transfer modeling. The water permeability coefficient of the $\mathrm{NH}_{4} \mathrm{Cl}$ solution $\left(1.29 \mathrm{~L} / \mathrm{m}^{2} \mathrm{~h}\right.$ bar $)$ and $\mathrm{NaCl}$ solution $\left(1.35 \mathrm{~L} / \mathrm{m}^{2} \mathrm{~h}\right.$ bar) were determined by linear fitting of water flux vs. net driving force, as $J_{v}=A\left(\Delta p-R_{a p p, s} \pi_{f, s}\right)$. However, the salt transport did not show a linear relationship with concentration difference as proposed in classical solution-diffusion theories. Thus, a power function equation as $J_{s}=\beta\left(C_{f, s}-C_{p, s}\right)^{\alpha}$ was proposed to explain the relationship among the feed concentration, water flux, and apparent salt rejection, aimed at the interpretation of the salt transport. All the predicted transport coefficients agreed well with the experimental data, and the models were also validated by real wastewater from a rare earth smeltery. The fundamental study on the elucidation of mass-transfer performance can provide insights to facilitate the application of $\mathrm{RO}$ in the treatment of wastewater from the rare earth industry, and to fill the knowledge gaps of understanding the mass transfer mechanism in the $\mathrm{RO}$ process.

Author Contributions: Formal analysis, S.G. and Z.M.; investigation S.G., Z.M. and J.F.; project administration, Z.M. and J.W.; supervision, J.W. and Y.W.; writing—original draft preparation, S.G. and Z.M.; writing review and editing, Z.M. and J.W.; funding acquisition, Z.M. All authors have read and agreed to the published version of the manuscript.

Funding: This work was supported by the National Natural Science Foundation of China (No. 21567009), the Jiang Xi Association for Science and Technology, and the Key Program of Jiangxi Academy of Sciences (2017-YZD2-14, 2018-YZD2-02).

Acknowledgments: We thank all the authors who contributed to this article.

Conflicts of Interest: The authors declare no conflict of interest.

\section{References}

1. Hatje, V.; Bruland, K.W.; Flegal, A.R. Increases in Anthropogenic Gadolinium Anomalies and Rare Earth Element Concentrations in San Francisco Bay over a 20 Year Record. Environ. Sci. Technol. 2016, 50, 4159-4168. [CrossRef] [PubMed]

2. Chen, J.Y.; Zhu, X.H.; Liu, G.; Chen, W.Q.; Yang, D.H. China's rare earth dominance: The myths and the truths from an industrial ecology perspective. Resour. Conserv. Recycl. 2018, 132, 139-140. [CrossRef]

3. Wang, L.S.; Huang, X.W.; Yu, Y.; Xiao, Y.F.; Long, Z.Q.; Cui, D.L. Eliminating ammonia emissions during rare earth separation through control of equilibrium acidity in a HEH(EHP)-Cl system. Green Chem. 2013, 15, 1889-1894. [CrossRef]

4. Yin, S.H.; Chen, K.H.; Srinivasakannan, C.; Guo, S.H.; Li, S.W.; Peng, J.H.; Zhang, L.B. Enhancing recovery of ammonia from rare earth wastewater by air stripping combination of microwave heating and high gravity technology. Chem. Eng. J. 2018, 337, 515-521. [CrossRef]

5. China Ministry of Environmental Protection, Emission Standards of Pollutants from Rare Earths Industry GB 26451-2011 (in Chinese), Beijing, China. Available online: http://www.mee.gov.cn/ywgz/fgbz/bz/bzwb/ shjbh/swrwpfbz/201102/t20110210_200521.shtml (accessed on 1 October 2011).

6. Huang, H.M.; Xiao, X.M.; Yan, B. Complex treatment of the ammonium nitrogen wastewater from rare-earth separation plant. Desalin. Water Treat. 2009, 8, 109-117. [CrossRef]

7. Huang, H.M.; Xiao, X.M.; Yang, L.P.; Yan, B. Removal of ammonia nitrogen from washing wastewater resulting from the process of rare-earth elements precipitation by the formation of struvite. Desalin. Water Treat. 2010, 24, 85-92. [CrossRef]

8. Li, Y.; Shi, S.Y.; Cao, H.B.; Wu, X.M.; Zhao, Z.J.; Wang, L.Y. Bipolar membrane electrodialysis for generation of hydrochloric acid and ammonia from simulated ammonium chloride wastewater. Water Res. 2016, 89, 201-209. [CrossRef]

9. Malaeb, L.; Ayoub, G.M. Reverse osmosis technology for water treatment: State of the art review. Desalination 2011, 267, 1-8. [CrossRef]

10. Pontié, M.; Charcosset, C. Seawater. Brackish Waters, and Natural Waters Treatment with Hybrid Membrane Processes. In Integrated Membrane Systems and Processes, 7th ed.; Basile, A., Charcosset, C., Eds.; John Wiley \& Sons Ltd.: Hoboken, NJ, USA, 2016; pp. 165-192. [CrossRef] 
11. Zhang, L.N.; Xu, B.H.; Gong, J.D.; Bu, T.D. Membrane combination technic on treatment and reuse of high ammonia and salts wastewater in rare earth manufacture process. J. Rare Earths 2010, 28, 501-503. [CrossRef]

12. Huang, H.M.; Fu, Z.; Xiao, X.M.; Yan, B. Study on treatment of rare-earth ammonium nitrogen wastewater by reverse osmosis(in Chinese). Chin. J. Environ. Eng. 2009, 3, 1443-1446.

13. Chang, I.S.; Chung, C.M. Pollution prevention for manufacturing of ammonium chloride-an experimental study of wastewater recycling. Desalination 2000, 127, 145-153. [CrossRef]

14. Bódalo, A.; Gómez, J.L.; Gómez, E.; León, G.; Tejera, M. Ammonium removal from aqueous solutions by reverse osmosis using cellulose acetate membranes. Desalination 2005, 184, 149-155. [CrossRef]

15. Häyrynen, K.; Pongrácz, E.; Väisänen, V.; Pap, N.; Mänttäri, M.; Langwaldt, J.; Keiski, R.L. Concentration of ammonium and nitrate from mine water by reverse osmosis and nanofiltration. Desalination 2009, 240, 280-289. [CrossRef]

16. Park, H.B.; Kamcev, J.; Robeson, L.M.; Elimelech, M.; Freeman, B.D. Maximizing the right stuff: The trade-off between membrane permeability and selectivity. Science 2017, 356, eaab0530. [CrossRef] [PubMed]

17. Merten, U. Flow Relationships in Reverse Osmosis. Ind. Eng. Chem. Fundam. 1963, 2, 229-232. [CrossRef]

18. Lonsdale, H.K.; Merten, U.; Riley, R.L. Transport properties of cellulose acetate osmotic membranes. J. Appl. Polym. Sci. 1965, 9, 1341-1362. [CrossRef]

19. Wijmans, J.G.; Baker, R.W. The solution-diffusion model: A review. J. Membr. Sci. 1995, 107, 1-21. [CrossRef]

20. Paul, D.R. Reformulation of the solution-diffusion theory of reverse osmosis. J. Membr. Sci. 2004, 241, 371-386. [CrossRef]

21. Geise, G.M.; Paul, D.R.; Freeman, B.D. Fundamental water and salt transport properties of polymeric materials. Prog. Polym. Sci. 2014, 39, 1-42. [CrossRef]

22. Hung, L.Y.; Lue, S.J.; You, J.H. Mass-transfer modeling of reverse-osmosis performance on $0.5-2 \%$ salty water. Desalination 2011, 265, 67-73. [CrossRef]

23. Zaidi, S.M.J.; Fadhillah, F.; Khan, Z.; Ismail, A.F. Salt and water transport in reverse osmosis thin film composite seawater desalination membranes. Desalination 2015, 368, 202-213. [CrossRef]

24. Zhou, W.; Somh, L. Experimental study of water and salt fluxes through reverse osmosis membranes. Environ. Sci. Technol. 2005, 39, 3382-3387. [CrossRef] [PubMed]

25. Akin, O.; Temelli, F. Probing the hydrophobicity of commercial reverse osmosis membranes produced by interfacial polymerization using contact angle, XPS, FTIR, FE-SEM and AFM. Desalination 2011, 278, 387-396. [CrossRef]

26. Mai, Z.H.; Butin, V.; Rakib, M.; Zhu, H.C.; Rabiller-Baudry, M.; Couallier, E. Influence of bulk concentration on the organization of molecules at a membrane surface and flux decline during reverse osmosis of an anionic surfactant. J. Membr. Sci. 2016, 499, 257-268. [CrossRef]

27. Mai, Z.H.; Gui, S.L.; Fu, J.Q.; Jiang, C.; Ortega, E.; Zhao, Y.; Tu, W.Q.; Mickols, W.; Bruggen, B.V. Activity-derived model for water and salt transport in reverse osmosis membranes: A combination of film theory and electrolyte theory. Desalination 2019, 469, 114094. [CrossRef]

28. Stevens, D.M.; Shu, J.Y.; Reichert, M.; Roy, A. Next-Generation Nanoporous Materials: Progress and Prospects for Reverse Osmosis and Nanofiltration. Ind. Eng. Chem. Res. 2017, 56, 10526-10551. [CrossRef]

29. Yan, Z.Q.; Zeng, L.M.; Li, Q.; Liu, T.Y.; Matsuyama, H.; Wang, X.L. Selective separation of chloride and sulfate by nanofiltration for high saline wastewater recycling. Sep. Purif. Technol. 2016, 166, 135-141. [CrossRef]

30. Kim, S.H.; Kwak, S.Y.; Suzuki, T. Positron annihilation spectroscopic evidence to demonstrate the flux-enhancement mechanism in morphology-controlled thin-film-composite (TFC) membrane. Environ. Sci. Technol. 2005, 39, 1764-1770. [CrossRef]

31. Somrani, A.; Hamzaoui, A.H.; Pontie, M. Study on lithium separation from salt lake brines by nanofiltration (NF) and low pressure reverse osmosis (LPRO). Desalination 2013, 317, 184-192. [CrossRef]

32. Houriez, C.; Real, F.; Vallet, V.; Mautner, M.; Masella, M. Ion hydration free energies and water surface potential in water nano drops: The cluster pair approximation and the proton hydration Gibbs free energy in solution. J. Chem. Phys. 2019, 151, 174504. [CrossRef]

33. Mohamedou, E.O.; Suarez, D.B.P.; Vince, F.; Jaouen, P.; Pontie, M. New lives for old reverse osmosis (RO) membranes. Desalination 2010, 253, 62-70. [CrossRef]

34. Pontie, M.; Diawara, C.K.; Rumeau, M. Streaming effect of single electrolyte mass transfer in nanofiltration: Potential application for the selective defluorination of brackish drinking waters. Desalination 2002, 151, 267-274. [CrossRef] 
35. Mickols, W. Substantial Changes in the Transport Model of Reverse Osmosis and Nanofiltration by Incorporating Accurate Activity Data of Electrolytes. Ind. Eng. Chem. Res. 2016, 55, 11139-11149. [CrossRef]

36. Jang, E.S.; Mickols, W.; Sujanani, R.; Helenic, A.; Dilenschneider, T.J.; Kamcev, J.; Paul, D.R.; Freeman, B.D. Influence of Concentration Polarization and Thermodynamic Non-ideality on Salt Transport in Reverse Osmosis Membranes. J. Membr. Sci. 2019, 572, 668-675. [CrossRef]

(C) 2020 by the authors. Licensee MDPI, Basel, Switzerland. This article is an open access article distributed under the terms and conditions of the Creative Commons Attribution (CC BY) license (http://creativecommons.org/licenses/by/4.0/). 